\title{
Pregnancy-Associated Alterations of Peripheral Blood Immune Cell Numbers in Domestic Sows Are Modified by Social Rank
}

\author{
Christiane Schalk, Birgit Pfaffinger, Sonja Schmucker *, Ulrike Weiler and Volker Stefanski * \\ Department of Behavioral Physiology of Livestock, Institute of Animal Science, University of Hohenheim, \\ Garbenstr 17, 70599 Stuttgart, Germany; christiane_schalk@uni-hohenheim.de (C.S.); \\ birgit.pfaffinger@uni-hohenheim.de (B.P.); weiler@uni-hohenheim.de (U.W.) \\ * Correspondence: sonja.schmucker@uni-hohenheim.de (S.S.); volker.stefanski@uni-hohenheim.de (V.S.); \\ Tel.: +49-711-459-22460 (S.S.); +49-711-459-22455 (V.S.)
}

Received: 10 February 2019; Accepted: 21 March 2019; Published: 23 March 2019

Simple Summary: During pregnancy, the maternal immune system is characterized by changes in various immune functions. Nevertheless, pregnancy-associated immune changes and the interplay of rank-associated and gestation-induced immunomodulations are still poorly investigated in sows. Important aspects of blood cellular immunity, cortisol concentrations, and the influence of social rank position during pregnancy were investigated. The results showed that the numbers of various lymphocyte subpopulations decreased, while neutrophils and plasma cortisol concentrations increased during pregnancy. Those pregnancy-associated alterations in the immune system were affected especially in middle-ranking sows, indicating that social rank can influence the immune system and endocrine status in sows during pregnancy.

\begin{abstract}
During pregnancy, the maternal immune system is characterized by a shift from adaptive to innate immune functions. Besides, the immune system can be influenced by social rank. Detailed knowledge of pregnancy-associated immune changes and of the interplay of rank-associated and gestation-induced immunomodulations is still fragmentary in sows. This study investigates both the numbers of various blood leukocyte subpopulations during pregnancy and the influence of social rank position on progressing pregnancy-associated alterations in group-housed sows. Sows were classified as low (LR), middle (MR), or high-ranking (HR). Five blood samples were collected from each of the 35 sows throughout pregnancy to evaluate the distribution of blood lymphocyte subpopulations and plasma cortisol concentrations. The numbers of $\mathrm{T}$, natural killer (NK), and B cells, cytotoxic $\mathrm{T}$ cells (CTL), and $\mathrm{CD}^{+} \gamma \delta-\mathrm{T}$ cells decreased during the last trimester of pregnancy, while neutrophils and plasma cortisol concentration increased before parturition. Social rank revealed different effects on B cells and monocytes with MR sows showing higher numbers than LR sows. Plasma cortisol concentrations also tended to be higher in MR sows as compared to LR sows. In conclusion, sows show pregnancy-associated alterations in the immune system, which are influenced by social rank, as middle-ranking sows in particular display signs of stress-induced immunomodulations.
\end{abstract}

Keywords: blood leukocyte subsets; cortisol; gestation; pig; reproduction; social rank

\section{Introduction}

The maternal immune system undergoes unique changes during gestation. Profound alterations in numbers and functionality of immune cells occur from the first trimester of pregnancy onwards. These adjustments are generally characterized by a shift from adaptive to innate immune functions $[1,2]$. On the level of the peripheral blood, this change is reflected in increased numbers of circulating 
granulocytes, monocytes, and dendritic cells (DC) while the numbers of T, B, and natural killer (NK) cells decrease [3-7]. This immune status, unique to pregnancy, is crucial for reproductive performance by achieving a successful pregnancy, but also for maternal health [8-10]. In contrast to rodents and humans, knowledge on pregnancy-associated immune changes in sows is fragmentary. Previous research investigated either broad measures of leukocyte blood counts [11-14] or an analysis of functionally distinct lymphocyte subsets, such as T helper (TH) cells, cytotoxic T cells (CTL), B cells, and NK cells, was not conducted during the entire pregnancy $[11,15,16]$.

Moreover, it is well established that the social environment has a profound impact on the immune system in group-living species, including the pig [16-20], and that the immune competence of an individual can be strongly related to its social rank [4,21]. However, little is known on the interplay of rank-associated and gestation-induced immunomodulations in sows. This is rather surprising, considering that group-housing of sows is increasing worldwide and is mandatory, e.g., in the European Union (EU directive 2001/88/EC), for most of the pregnancy. In sows, several behavioral studies indicate that a low or intermediate social rank is associated with received aggressive behavior, poorer physical condition, lower body weight gain [22-24], and higher cortisol concentrations [23,25-28]. Considering the well-known immunomodulatory properties of cortisol [29,30], an effect of social rank on the T and B cell distribution is likely, with possible consequences for maternal and fetal health as well. However, most of the studies to date found no effects of social status on immune measures, such as the numbers of blood granulocytes and lymphocytes, lymphocyte proliferation, or antibody response, in pregnant sows $[15,27,31]$. Only Pacheco and Salak-Johnson [32] reported higher plasma cytokine levels (Interleukin-12) in blood plasma, and a reduced percentage of blood neutrophils in submissive pregnant sows as compared to dominants. Nevertheless, the conclusion that there is only little interplay between social status and pregnancy-associated immune system alterations should be considered premature as long as an assessment of the distribution pattern of the distinct lymphocyte subsets is missing. This view is also supported by data from non-pregnant female pigs, in which the clear influence of social rank on blood immune cell numbers after regrouping or changes in thermal environment is evident $[33,34]$.

The aim of the present study was to investigate the numbers of various blood leukocyte subpopulations during all trimesters of pregnancy in group-housed multiparous sows with special emphasis on the question whether the social status of sows affects the progress of pregnancy-associated alterations.

\section{Materials and Methods}

\subsection{Animals and Housing}

A total of 40 multiparous German Landrace sows (parity number $4.3 \pm 1.8$ ) in two replicates of 20 sows each was included in this study. All animals were kept at the Agricultural Experiment Station of the University of Hohenheim (Unterer Lindenhof, Eningen unter Achalm, Germany) and housed according to the ethical and animal care guidelines (approved by the Committee on the Ethics of Animal Experiments of the Regional Commission of Tübingen, Germany; Ethical approval code: $\mathrm{HOH} 29 / 13)$. All sows were artificially inseminated with Pietrain semen and housed in groups of five animals, which were balanced by parity, body mass, and age at the beginning of the experiment. The sows were $819.4 \pm 319.5$ days of age and weighed $229.9 \pm 41.4 \mathrm{~kg}$ at the beginning of pregnancy.

During gestation, sows had free access to water and were fed once a day at 08:00 AM with a standard barely-wheat-oat-based diet according to the actual metabolic requirements for pregnant sows ( $\leq$ day 84 of pregnancy: $2.5 \mathrm{~kg} /$ day; $\geq$ day 85 of pregnancy: $3.0 \mathrm{~kg} /$ day). Pens (approximately $16 \mathrm{~m}^{2}$ ) consisted of concrete flooring and solid wooden walls that restricted physical and visual contact between groups. For individual identification, all sows were marked with a commercial colored spray on the back and both sides of the body. All animals remained in a constant group composition over a period of four weeks after insemination. Afterwards, sows were housed in stable or dynamic group 
compositions (4 groups; dynamic from week 11-4 pre partum). In the dynamic groups, the composition was changed twice a week over eight weeks until four weeks before farrowing while the other sows stayed in a stable group composition during the entire pregnancy.

\subsection{Blood Collection}

Five blood samples were collected via jugular vein puncture during gestation from each pregnant sow (individual sampling duration $<2 \mathrm{~min}$ ). For blood sampling, sows were restrained using a nose snare. Blood samples were collected between 09:00-10:00 AM into lithium heparin tubes and K3 EDTA tubes (both Sarstedt, Nümbrecht, Germany). One sample was obtained during the first trimester of pregnancy (week 12 pre partum), two additional samples during the second trimester (week 10 and 7 pre partum), and two samples during the last trimester of pregnancy (week 4 and 2 pre partum). All samples were processed within $3 \mathrm{~h}$ after sampling.

\subsection{Cortisol Measurement}

Cortisol concentrations were determined radioimmunologically in blood plasma samples after ethanolic extraction as described previously [35]. Plasma was obtained from heparinized blood samples by centrifugation $\left(1000 \times g\right.$ for $10 \mathrm{~min}$ at $\left.10^{\circ} \mathrm{C}\right)$ and stored at $-20^{\circ} \mathrm{C}$ until assayed. [1.2,-3H]-cortisol (50 Ci/mmol, Hartmann Analytic, Braunschweig, Germany) was used as a tracer. Standards were prepared in charcoal-stripped plasma with final concentrations ranging from 2 to $200 \mathrm{ng} \mathrm{cortisol} / \mathrm{mL}$ (Sigma-Aldrich, Munich, Germany). The coefficients of the inter-assay variation ranged between $13.9 \%$ and $8.5 \%$ depending on the endogenous concentration of the samples $(13.6$ and $39.9 \mathrm{ng} / \mathrm{mL}$, respectively). The coefficient of intra-assay variability was $8.4 \%$. The precision was determined by calculating the recovery rate of cortisol spiked samples (10, 20, and $40 \mathrm{ng} / \mathrm{mL}$ ) and was $91 \%$ on average.

\subsection{Differential Blood Count}

The percentage of leukocyte and lymphocyte subpopulations in heparinized whole-blood was quantified by flow cytometry by a three-color immunofluorescent antibody staining procedure as described previously [36]. In detail, specific immune cell populations were characterized by use of different combinations of the following fluorochrome-labeled pig-specific antibodies directed against the cell surface markers: CD3 (clone PPT3), CD4 (clone 74-12-4), CD8 $\alpha$ (clone 76-2-11), and CD172a (clone 74-22-15) (all SouthernBiotech, Birmingham, AL, USA). In brief, peripheral blood mononuclear cells (PBMC) and granulocytes were identified by their forward and side scatter characteristics. Granulocyte subpopulations were further differentiated into neutrophils and eosinophils by autofluorescence characteristics within the unstained control sample. PBMC subpopulations were classified by light scatter properties and the combination of surface marker expression as follows: $\mathrm{T}$ cells $\left(\mathrm{SSC}^{-} \mathrm{CD}^{+}\right)$, naive $\mathrm{T}$ helper $(\mathrm{TH})$ cells $\left(\mathrm{SSC}^{-} \mathrm{CD}^{+} \mathrm{CD}^{+} \mathrm{CD}^{-} \alpha^{-}\right)$, antigen-experienced $\mathrm{TH}$ cells $\left(\mathrm{SSC}^{-} \mathrm{CD}^{+} \mathrm{CD}^{+} \mathrm{CD} 8 \alpha^{+}\right.$), cytotoxic $\mathrm{T}$ cells $(\mathrm{CTL})\left(\mathrm{SSC}^{-} \mathrm{CD}^{+}\right.$ $\left.\mathrm{CD} 4^{-} \mathrm{CD} 8 \alpha^{\text {high}}\right), \gamma \delta-\mathrm{T}$ cells (SSC $\left.{ }^{-} \mathrm{CD}^{+} \mathrm{CD}^{-} \mathrm{CD} 8 \alpha^{-/ \operatorname{dim}}\right)$, natural killer $(\mathrm{NK})$ cells $\left(\mathrm{SSC}^{-} \mathrm{CD}^{-}\right.$ $\left.\mathrm{CD} 8 \alpha^{+}\right)$, and monocytes (SSC $\left.{ }^{-} \mathrm{CD}^{-} \mathrm{CD} 8 \alpha^{-} \mathrm{CD} 172 \mathrm{a}^{\text {high }}\right)$. B cells were characterized by negative discrimination (SSC ${ }^{-} \mathrm{CD}^{-} \mathrm{CD} 8 \alpha^{-} \mathrm{CD}^{-} 172 \mathrm{a}^{-}$), which should characterize no other porcine blood immune cell fraction than B cells.

Total leukocyte counts were determined in EDTA whole blood by an automated hematology system (pocH 100-iV Diff, Sysmex, Norderstedt, Germany) and absolute numbers of the different immune cell populations in the blood were determined by combining cell frequencies obtained from the flow cytometric assessment with these total leukocyte counts.

\subsection{Behavioral Recording and Rank Classification}

Behavior patterns and their descriptions are listed in the ethogram shown in Table $1[37,38]$. 
Table 1. Ethogram of aggressive and submissive behavior observed in pregnant sows.

\begin{tabular}{|c|c|}
\hline Behavior & Description \\
\hline \multicolumn{2}{|r|}{ Aggressive } \\
\hline Biting & $\begin{array}{l}\text { Biting with teeth at another sow's head and body. Mouth of the acting sow is } \\
\text { open. The attempt is also evaluated. }\end{array}$ \\
\hline Head-to-body/head knocking & $\begin{array}{l}\text { A rapid, heavy thrust or push upwards or sideways with head or snout against } \\
\text { another sow's body or head. }\end{array}$ \\
\hline Parallel pressing & $\begin{array}{l}\text { Two sows standing side by side and pushing their shoulders and bodies against } \\
\text { each other. With or without biting and head-to-head knock. }\end{array}$ \\
\hline Inverse parallel pressing & $\begin{array}{l}\text { Two sows standing face front to front and push their shoulders, bodies and } \\
\text { heads against each other. With or without biting and head-to-body knock. }\end{array}$ \\
\hline Following/Chasing & $\begin{array}{l}\text { Moving at a walking or running pace more than } 3 \text { steps in pursuit of another } \\
\text { sow and reducing the distance between both animals to less than } 1 \mathrm{~m} \text {. } \\
\text { The receiver sow withdraws or flees. }\end{array}$ \\
\hline Displacing & $\begin{array}{l}\text { Forcing another sow to leave and avoid its current location, lying place, trough, } \\
\text { or drinker by appearance alone, without any physical contact. The receiver sow } \\
\text { avoids the intruder. }\end{array}$ \\
\hline \multicolumn{2}{|r|}{ Submissive } \\
\hline Avoiding & $\begin{array}{l}\text { Result of "displacing". Leaving and avoiding ( }>2 \text { steps) the current location, } \\
\text { lying place, trough, or drinker caused only by another sow's appearance, not by } \\
\text { any physical contact. }\end{array}$ \\
\hline Withdrawing & $\begin{array}{l}\text { Possible result of any aggressive behavior. Moving away ( }>2 \text { steps) from } \\
\text { another sow at a walking pace. }\end{array}$ \\
\hline Fleeing & $\begin{array}{l}\text { Possible result of any aggressive behavior. Moving away ( }>3 \text { steps) from } \\
\text { another sow at a running pace. }\end{array}$ \\
\hline
\end{tabular}

Agonistic behavior was analyzed with video cameras (Viewex-350/WS; Monacor International, Bremen, Germany) by continuous recording for four hours at defined time-points during the entire pregnancy (week 13, 10, 8, 6, 4, and 2 pre partum) to determine the number of agonistic interactions, the initiating sow, and the outcome (win or defeat).

The data gathered from the recorded interactions per group were transferred into a winner-loser matrix. Based on these matrices, a modified Average Dominance Index (ADI) for each sow was calculated by using DomiCalc [39] following the formula:

$$
\mathrm{ADI}=\frac{1}{n} \Sigma \omega_{i j}
$$

Per pair of individuals, $\omega_{i j}$ is calculated as the number of times a sow, $i$, won against another sow, $j$ $\left(x_{i j}\right)$, divided by the total number of agonistic interactions between the two sows, thus $\omega_{i j}=x_{i j} /\left(x_{i j}+x_{j i}\right)$. The ADI value of one individual is the average of all its dominance indices with all its interaction partners and varies from 0 to 1 , with a higher value indicating a higher dominance rank in the group [40,41].

For each sow, an average ADI was calculated (mean value resulting from six observations). Animals receiving a mean value between $0.00-0.33$ were categorized as low-ranking (LR), between $0.34-0.65$ as middle-ranking (MR), and between $0.66-1.00$ as high-ranking (HR) sows.

\subsection{Statistical Analyses}

Data of 35 pregnant sows (HR: 8; MR: 15; LR: 12) were included in the statistical analyses as sows with recurring estrous were excluded and one sow had to be removed from the experiment due to leg injuries.

Statistical models used R programming language version 3.1.0 [42] and the function "lmer" of the R package lme4 [43]. Linear mixed-effect models included the factors week of pregnancy, social rank, and their interaction as fixed effects as well as housing, replicate, and individual as random effects. Sampling duration and age were included as covariates in each model and were excluded if no 
significant effects $(p>0.1)$ could be observed. Body mass and number of litters were not included due to a positive correlation with age.

Residuals of immunological parameters and cortisol were examined for normal distribution with the Shapiro-Wilk test, as well as for homogeneity of variance by a plot of the fitted values against the residuals. If model assumptions were not fulfilled, logarithmic or square root transformations were used to stabilize variance and meet the distribution assumption.

All data were considered significant at $p<0.05$ and at $0.05<p<0.10$ as a tendency and are expressed as least square means with pooled standard error of the mean (SEM) inferred from the linear mixed effect model. The adjusted mean estimates from models with a transformed response variable are reported on the original scale after back transformation.

The levels of factors found to be significant were compared by pairwise Tukey tests using the function "glht" [44] of the R package multcomp [45].

Spearman's rank correlations were performed to evaluate possible relationships between plasma cortisol levels and blood immune cell numbers across all time points and social ranks.

\section{Results}

\subsection{Pregnancy-Induced Alterations in Numbers of Blood Immune Cells and Cortisol Concentration}

Numbers of blood immune cells and cortisol concentrations during pregnancy are shown in Table 2. Linear-mixed effect models revealed that all physiological parameters were influenced by week of pregnancy. Post hoc analysis of pregnancy-associated alterations showed that the numbers of many lymphocytes remained constant during the first and second trimester of pregnancy (until week 7 pre partum), but decreased during the last trimester (from week 4 pre partum onwards).

Precisely, this pattern was found in T cells, NK cells, B cells, CTL, and CD $8^{+} \gamma \delta$-T cells (see Table 2 for statistical details). Among the TH cell subsets, a differential onset of decline was observed. The number of $\mathrm{CD} 8 \alpha^{+}$antigen-experienced TH cells already declined during mid-pregnancy (from week 7 pre partum) while the number of naive TH cells decreased sharply only shortly before parturition (week 2 pre partum). The change of the number of $\mathrm{CD} 8^{-} \gamma \delta-\mathrm{T}$ cells differed from all other subsets. Instead of declining, their number increased slightly in mid-pregnancy and returned to starting levels just at the end of pregnancy.

Analysis of antigen-presenting cell types revealed a decrease in the number of monocytes with progressing pregnancy. The number of neutrophils and, in consequence, the ratio of neutrophils:lymphocytes increased shortly before parturition. In contrast, the number of blood eosinophils decreased during pregnancy (Table 2).

Plasma cortisol concentrations increased at the end of pregnancy (week 2 pre partum), but did not differ during the beginning and middle of gestation (Table 2). 
Table 2. Count of blood leukocytes and lymphocyte subpopulations in sows at defined weeks pre partum.

\begin{tabular}{|c|c|c|c|c|c|c|c|}
\hline \multirow{2}{*}{ Count $/ \mu \mathrm{L}$ Blood } & \multicolumn{6}{|c|}{ Weeks Pre Partum } & \multirow{2}{*}{$\begin{array}{c}p \text {-Value } \\
\text { Week of Pregnancy }\end{array}$} \\
\hline & 12 & 10 & 7 & 4 & 2 & Pooled SEM & \\
\hline Lymphocytes (L) $^{+}$ & $5488^{a}$ & $5349^{a}$ & $5298^{a}$ & $4882^{b}$ & $4170^{c}$ & 356 & $<0.001$ \\
\hline $\mathrm{T}$ cells $\ddagger$ & $4537^{\mathrm{a}}$ & $4458^{a}$ & $4316^{a b}$ & $4100^{\mathrm{b}}$ & $3383^{c}$ & 162 & $<0.001$ \\
\hline$B$ cells ${ }^{+}$ & $840^{a b}$ & $774^{\mathrm{a}}$ & $860^{\mathrm{b}}$ & $683^{c}$ & $689^{c}$ & 167 & $<0.001$ \\
\hline NK cells ${ }^{\dagger}$ & $121^{\mathrm{a}}$ & $112^{a}$ & $120^{a}$ & $108^{a}$ & $86^{\mathrm{b}}$ & 20 & $<0.001$ \\
\hline Cytotoxic T cells $\ddagger$ & $1162^{a}$ & $1099 \mathrm{ab}$ & $1111^{\mathrm{a}}$ & $1011^{b}$ & $847^{c}$ & 100 & $<0.001$ \\
\hline Total TH cells ${ }^{+}$ & $2359^{a}$ & $2291^{a b}$ & $2101^{b}$ & $2121^{b}$ & $1699^{c}$ & 91 & $<0.001$ \\
\hline Naive $\mathrm{TH}$ cells ${ }^{\dagger}$ & $549^{a}$ & $573^{a}$ & $518^{a}$ & $537^{\mathrm{a}}$ & $433^{\mathrm{b}}$ & 56 & $<0.001$ \\
\hline $\mathrm{CD} 8 \alpha^{+} \mathrm{TH}$ cells ${ }^{\dagger}$ & $1736^{a}$ & $1647^{a b}$ & $1523^{b}$ & $1518^{b}$ & $1225^{c}$ & 72 & $<0.001$ \\
\hline Total $\gamma \delta$-T cells & $1002^{a b}$ & $1046^{\mathrm{a}}$ & $1032^{\mathrm{a}}$ & $913^{b}$ & $805^{c}$ & 102 & $<0.001$ \\
\hline $\mathrm{CD}^{+} \gamma \delta-\mathrm{T}$ cells $\ddagger$ & $751^{\mathrm{a}}$ & $759^{a}$ & $745^{a}$ & $645^{b}$ & $563^{c}$ & 78 & $<0.001$ \\
\hline CD $8^{-} \gamma \delta$-T cells $\ddagger$ & $202^{a}$ & $233^{b}$ & $242^{b}$ & $224^{\mathrm{ab}}$ & $198^{\mathrm{a}}$ & 20 & $<0.001$ \\
\hline Neutrophils (N) ${ }^{\dagger}$ & $3101^{a}$ & $2985^{a}$ & $2908^{a}$ & $2947^{\mathrm{a}}$ & $3552^{b}$ & 143 & $<0.001$ \\
\hline Eosinophils $\ddagger$ & $532^{\mathrm{a}}$ & $457 \mathrm{bc}$ & $428^{b c}$ & $483^{\mathrm{ab}}$ & $412^{c}$ & 34 & $<0.001$ \\
\hline Monocytes $^{\dagger}$ & $668^{a}$ & $641^{\mathrm{ab}}$ & $663^{a b}$ & $614^{\mathrm{ab}}$ & $602^{b}$ & 50 & $<0.05$ \\
\hline Ratio of N:L $\mathrm{L}^{+}$ & $0.6^{\mathrm{a}}$ & $0.6^{\mathrm{a}}$ & $0.6^{\mathrm{a}}$ & $0.6^{\mathrm{a}}$ & $0.9^{b}$ & 0.05 & $<0.001$ \\
\hline Cortisol $^{\dagger}, \mathrm{ng} / \mathrm{mL}$ plasma & $16.4^{\mathrm{a}}$ & $16.9^{\mathrm{a}}$ & $18.9^{\mathrm{a}}$ & $19.0^{\mathrm{a}}$ & $25.0^{\mathrm{b}}$ & 1.92 & $<0.001$ \\
\hline
\end{tabular}

Data are expressed as least-square means with pooled standard error of the mean (SEM). Adjusted mean estimates from models with ${ }^{\dagger}$ logarithmic or ${ }^{\ddagger}$ square root transformed response variable are reported on the original scale after back transformation. $p$-Values indicate a significant effect of the week of pregnancy. Different superscripts ${ }^{a, b}, \mathrm{c}$ within a row indicate the weeks of pregnancy ( 12 vs. 10,12 vs. 7,12 vs. 4,12 vs. 2,10 vs. 7,10 vs. 4,10 vs. 2,7 vs. 4,7 vs. 2,4 vs. 2 ) that significantly differ after post-hoc testing $(p<0.05)$ for the respective immune cell type. 


\subsection{Effects of Social Status on Numbers of Blood Immune Cells and Cortisol Concentration}

Statistical analysis further indicated that there was no significant week of pregnancy $\times$ social rank interaction. While showing differences in the absolute numbers of some important immune cells, a comparable pattern of change during pregnancy existed in sows of all three rank positions.

Table 3 indicates that the social rank influenced B cells, with MR sows showing a higher number than LR sows at week 10, 7, and 2 pre partum. Monocytes were strongly influenced by social rank, whereas neutrophils did not differ between rank positions (Table 3). Monocyte numbers of MR sows were higher than in LR sows at week 7 and 4 pre partum and also tended to be higher at week 10 pre partum. There was a tendency for a higher number of monocytes in MR sows compared to HR sows at week 4 pre partum. The number of NK cells did not differ between social rank positions of sows (Table 3).

Compared to LR sows, plasma cortisol concentrations were higher in HR sows at the beginning of pregnancy and tended to be higher in MR sows at the beginning of the second trimester. At the end of pregnancy, HR and MR sows tended to have higher plasma cortisol levels than LR sows. No differences were found between MR and HR sows (Table 3).

Although the total T cell numbers did not differ among ranks (Table 3), an in-depth analysis showed relevant differences of the T cell subsets (Table 4). At week 2 pre partum, HR sows (and MR sows with a tendency) had a lower blood number of naive TH cells than LR sows, while a higher number of blood antigen-experienced CD8 $\alpha^{+} \mathrm{TH}$ cells were found in HR sows. At the start of pregnancy, rank-dependent differences could be seen for $\gamma \delta$-T cells. At week 12 pre partum LR sows had a higher number of total $\gamma \delta$-T cells than MR sows which resulted from a higher number of CD8 ${ }^{-}$ $\gamma \delta$-T cells. There was also a tendency for more total $\gamma \delta$-T cells in blood at week 10 pre partum in LR sows (Table 4). 
Table 3. Influence of social rank on count of blood immune cells and plasma cortisol concentration in high-ranking (HR), middle-ranking (MR), and low-ranking (LR) pregnant sows at defined weeks pre partum.

\begin{tabular}{|c|c|c|c|c|c|c|c|c|c|c|c|c|c|c|c|c|}
\hline $\begin{array}{c}\text { Item } \\
(\text { Count } / \mu \mathrm{L})\end{array}$ & $\begin{array}{c}\text { Rank } \\
\text { Position }\end{array}$ & 12 & $\begin{array}{c}\text { Pooled } \\
\text { SEM }\end{array}$ & $p$-Value & 10 & $\begin{array}{c}\text { Pooled } \\
\text { SEM }\end{array}$ & $p$-Value & 7 & $\begin{array}{c}\text { Pooled } \\
\text { SEM }\end{array}$ & $p$-Value & 4 & $\begin{array}{c}\text { Pooled } \\
\text { SEM }\end{array}$ & $p$-Value & 2 & $\begin{array}{c}\text { Pooled } \\
\text { SEM }\end{array}$ & $p$-Value \\
\hline \multirow{3}{*}{ Lymphocytes } & HR & +5048 & \multirow{3}{*}{533} & \multirow{3}{*}{0.2} & 5831 & \multirow{3}{*}{440} & \multirow{3}{*}{0.7} & +5634 & \multirow{3}{*}{410} & \multirow{3}{*}{0.64} & +5199 & \multirow{3}{*}{512} & \multirow{3}{*}{0.67} & +4482 & \multirow{3}{*}{386} & \multirow{3}{*}{0.49} \\
\hline & MR & +5827 & & & 5541 & & & ${ }^{+} 5349$ & & & ${ }^{+} 4802$ & & & ${ }^{\dagger} 4044$ & & \\
\hline & LR & +5846 & & & 5490 & & & +5045 & & & ${ }^{+} 4764$ & & & ${ }^{\dagger} 4112$ & & \\
\hline \multirow{3}{*}{$\mathrm{T}$ cells } & HR & ${ }^{+} 4701$ & \multirow{3}{*}{355} & \multirow{3}{*}{0.13} & 4701 & \multirow{3}{*}{340} & \multirow{3}{*}{0.77} & ${ }^{+} 4444$ & \multirow{3}{*}{353} & \multirow{3}{*}{0.72} & 4385 & \multirow{3}{*}{331} & \multirow{3}{*}{0.74} & 3576 & \multirow{3}{*}{267} & \multirow{3}{*}{0.45} \\
\hline & MR & +4090 & & & 4361 & & & ${ }^{+} 4152$ & & & 4067 & & & 3240 & & \\
\hline & LR & +4837 & & & 4531 & & & +4300 & & & 4100 & & & 3515 & & \\
\hline \multirow{3}{*}{ B cells } & HR & +977 & \multirow{3}{*}{153} & \multirow{3}{*}{0.47} & $936^{\mathrm{ab}}$ & \multirow{3}{*}{163} & \multirow{3}{*}{0.05} & $887^{a b}$ & \multirow{3}{*}{131} & \multirow{3}{*}{0.02} & 751 & \multirow{3}{*}{160} & & $746^{\mathrm{ab}}$ & & \\
\hline & MR & +843 & & & $919^{a}$ & & & $1108^{a}$ & & & 793 & & 0.12 & $821^{a}$ & 127 & 0.04 \\
\hline & LR & +769 & & & $670^{b}$ & & & $730^{\mathrm{b}}$ & & & 624 & & & $619^{b}$ & & \\
\hline & HR & ${ }^{+} 159$ & & & ${ }^{\dagger} 144$ & & & ${ }^{+} 152$ & & & ${ }^{+} 123$ & & & +99 & & \\
\hline NK cells & MR & ${ }^{\dagger} 101$ & 34 & 0.08 & ${ }^{\dagger} 100$ & 30 & 0.23 & ${ }^{\dagger} 114$ & 19 & 0.31 & +96 & 26 & 0.4 & +73 & 30 & 0.24 \\
\hline & LR & +139 & & & ${ }^{\dagger} 110$ & & & ${ }^{\dagger} 106$ & & & ${ }^{+} 112$ & & & +93 & & \\
\hline & HR & 3108 & & & 2916 & & & 3001 & & & ${ }^{+} 2499$ & & & +2957 & & \\
\hline Neutrophils & MR & 3353 & 294 & 0.74 & 3277 & 328 & 0.81 & 2960 & 244 & 0.98 & +3096 & 245 & 0.14 & +3690 & 333 & 0.2 \\
\hline & LR & 3110 & & & 3140 & & & 2950 & & & +3078 & & & +3781 & & \\
\hline & HR & +689 & & & $+593^{a b}$ & & & $759^{a b}$ & & & 604 at & & & 589 & & \\
\hline Monocytes & MR & +703 & 53 & 0.38 & $+705^{a}$ & 45 & 0.08 & $745^{\mathrm{a}}$ & 46 & 0.02 & $728^{b}$ & 55 & 0.003 & 656 & 67 & 0.26 \\
\hline & LR & +623 & & & $+593 \mathrm{bt}$ & & & $570^{b}$ & & & $534^{\mathrm{a}}$ & & & 585 & & \\
\hline Cortisol, & HR & $+31.8^{\mathrm{a}}$ & & & $20.7^{\mathrm{ab}}$ & & & 22.5 & & & 24.4 & & & $32.7^{\mathrm{a}}$ & & \\
\hline $\mathrm{ng} / \mathrm{mL}$ & MR & $+26.0 \mathrm{ab}$ & 2.9 & 0.02 & $22.0^{\text {at }}$ & 3.3 & 0.09 & 23.1 & 3.1 & 0.13 & 18.4 & 2.9 & 0.26 & $27.4^{\mathrm{a}}$ & 2.3 & 0.06 \\
\hline plasma & LR & ${ }^{+} 20.0^{b}$ & & & $14.6^{\mathrm{b}}$ & & & 17.5 & & & 21.0 & & & $20.4^{\mathrm{bt}}$ & & \\
\hline
\end{tabular}

Data are expressed as least-square means with pooled standard error of the mean (SEM). Adjusted mean estimates from models with ${ }^{\dagger}$ logarithmic transformed response variable are reported on the original scale after back transformation. $p$-Values indicate a significant effect of social rank at the respective week of pregnancy. Different superscripts ${ }^{a, b}$ within a column indicate the social rank positions (HR vs. MR, HR vs. LR, MR vs. LR) that significantly differ after post-hoc testing $(p<0.05)$ at the respective week pre partum for each immune cell type. Different superscripts at, bt within a column indicate the social rank positions (HR vs. MR, HR vs. LR, MR vs. LR) that tended to differ $(p<0.01)$ for each immune cell type at the respective week pre partum (HR with $N=8 ;$ MR with $N=15 ;$ LR with $N=12$ ). 
Table 4. Influence of social rank on the count of blood T cell subpopulations in high-ranking (HR), middle-ranking (MR), and low-ranking (LR) pregnant sows at defined weeks pre partum.

\begin{tabular}{|c|c|c|c|c|c|c|c|c|c|c|c|c|c|c|c|c|}
\hline $\begin{array}{c}\text { Item } \\
(\text { Count } / \mu \mathrm{L})\end{array}$ & $\begin{array}{c}\text { Rank } \\
\text { Position }\end{array}$ & 12 & $\begin{array}{c}\text { Pooled } \\
\text { SEM }\end{array}$ & $p$-Value & 10 & $\begin{array}{l}\text { Pooled } \\
\text { SEM }\end{array}$ & $p$-Value & 7 & $\begin{array}{l}\text { Pooled } \\
\text { SEM }\end{array}$ & $p$-Value & 4 & $\begin{array}{c}\text { Pooled } \\
\text { SEM }\end{array}$ & $p$-Value & 2 & $\begin{array}{c}\text { Pooled } \\
\text { SEM }\end{array}$ & $p$-Value \\
\hline \multirow{3}{*}{$\begin{array}{c}\text { Total TH } \\
\text { cells }\end{array}$} & HR & ${ }^{+} 2374$ & \multirow{3}{*}{194} & \multirow{3}{*}{0.52} & 2500 & \multirow{3}{*}{237} & \multirow{3}{*}{0.69} & ${ }^{+} 2078$ & \multirow{3}{*}{181} & \multirow{3}{*}{0.99} & ${ }^{+} 2377$ & \multirow{3}{*}{225} & \multirow{3}{*}{0.28} & ${ }^{+} 1854$ & \multirow{3}{*}{144} & \multirow{3}{*}{0.47} \\
\hline & MR & +2215 & & & 2299 & & & +2062 & & & +2074 & & & ${ }^{+} 1637$ & & \\
\hline & LR & +2477 & & & 2286 & & & +2090 & & & +2050 & & & $+{ }^{+} 1722$ & & \\
\hline \multirow{3}{*}{$\begin{array}{l}\text { Naive TH } \\
\text { cells }\end{array}$} & HR & ${ }^{+} 420$ & \multirow{3}{*}{80} & \multirow{3}{*}{0.14} & ${ }^{+} 495$ & \multirow{3}{*}{120} & \multirow{3}{*}{0.59} & ${ }^{+} 406$ & \multirow{3}{*}{70} & \multirow{3}{*}{0.23} & 508 & \multirow{3}{*}{121} & \multirow{3}{*}{0.74} & ${ }^{+} 303^{a}$ & \multirow{3}{*}{51} & \multirow{3}{*}{0.02} \\
\hline & MR & +568 & & & +599 & & & +550 & & & 585 & & & ${ }^{+} 429 \mathrm{bt}$ & & \\
\hline & LR & +682 & & & +620 & & & † 578 & & & 645 & & & ${ }^{+} 508^{b}$ & & \\
\hline \multirow{3}{*}{$\begin{array}{l}\mathrm{CD} 8 \alpha^{+} \mathrm{TH} \\
\text { cells }\end{array}$} & HR & ${ }^{+} 1859$ & \multirow{3}{*}{158} & \multirow{3}{*}{0.60} & ${ }^{\dagger} 1797$ & \multirow{3}{*}{161} & \multirow{3}{*}{0.33} & ${ }^{+} 1694$ & \multirow{3}{*}{153} & \multirow{3}{*}{0.76} & ${ }^{+} 1867$ & \multirow{3}{*}{175} & & $1609^{a}$ & & \\
\hline & MR & +1642 & & & ${ }^{+} 1650$ & & & ${ }^{+} 1486$ & & & +1504 & & 0.21 & $1201^{b}$ & 119 & 0.04 \\
\hline & LR & +1681 & & & ${ }^{+} 1488$ & & & ${ }^{+} 1403$ & & & +1392 & & & $1246^{\mathrm{bt}}$ & & \\
\hline & HR & ${ }^{+} 1161$ & & & 1090 & & & 1092 & & & 1072 & & & 966 & & \\
\hline CTL & MR & ${ }^{+} 1023$ & 163 & 0.22 & 1122 & 147 & 0.98 & 1132 & 123 & 0.95 & 1004 & 146 & 0.85 & 812 & 94 & 0.32 \\
\hline & LR & +1245 & & & 1125 & & & 1137 & & & 1057 & & & 879 & & \\
\hline & HR & $1094^{\text {at }}$ & & & $1146^{\mathrm{ab}}$ & & & 1020 & & & 905 & & & 750 & & \\
\hline Total $\gamma \delta-\mathrm{T}$ & MR & $803^{b}$ & 176 & 0.006 & $890^{\mathrm{a}}$ & 152 & 0.07 & 1005 & 102 & 0.75 & 828 & 182 & 0.38 & 707 & 189 & 0.15 \\
\hline & LR & $1236^{a}$ & & & $1172^{b t}$ & & & 1092 & & & 972 & & & 885 & & \\
\hline & HR & 793 & & & 845 & & & 774 & & & 689 & & & +555 & & \\
\hline $\mathrm{CD}^{+} \gamma \delta-\mathrm{T}$ & MR & 655 & 158 & 0.64 & $683^{a}$ & 106 & 0.07 & 744 & 130 & 0.88 & 608 & 130 & 0.34 & +514 & 118 & 0.70 \\
\hline & LR & 917 & & & $837^{b t}$ & & & 785 & & & 689 & & & +561 & & \\
\hline & HR & ${ }^{t} 150$ at & & & ${ }^{\dagger} 178$ & & & 257 & & & 224 & & & 166 & & \\
\hline CD8 ${ }^{-}$ & MR & ${ }^{\dagger} 160^{a}$ & 32 & 0.02 & +194 & 38 & 0.26 & 259 & 52 & 0.68 & 210 & 57 & 0.34 & 177 & 67 & 0.11 \\
\hline$\gamma \delta$-T cells & LR & ${ }^{+} 266^{b}$ & & & +248 & & & 303 & & & 288 & & & 276 & & \\
\hline
\end{tabular}

Data are expressed as least-square means with pooled standard error of the mean (SEM). Adjusted mean estimates from models with ${ }^{\dagger}$ logarithmic transformed response variable are reported on the original scale after back transformation. $p$-Values indicate a significant effect of social rank at the respective week of pregnancy. Different superscripts ${ }^{a, b}$ within a column indicate the social rank positions (HR vs. MR, HR vs. LR, MR vs. LR) that significantly differ after post-hoc testing $(p<0.05)$ at the respective week pre partum for each immune cell type. Different superscripts at, bt within a column indicate the social rank positions (HR vs. MR, HR vs. LR, MR vs. LR) that tended to differ ( $p<0.01)$ for each immune cell type at the respective week pre partum (HR with $N=8$; MR with $N=15 ;$ LR with $N=12$ ). 


\subsection{Correlation between Cortisol Concentration and Blood Immune Cell Numbers}

A possible relationship between cortisol levels and blood immune cell numbers was tested by Spearman's rank correlation. Analysis across all social ranks and over all time points $(N=175)$ showed a negative correlation for the plasma cortisol concentration with the number of $\mathrm{T}$ cells $(r<0.04$; $\rho=-0.15)$, total TH cells $(r<0.001 ; \rho=-0.25)$, naive TH cells $(r<0.02 ; \rho=-0.18)$, and CD8 $\alpha^{+} \mathrm{TH}$ cells $(r<0.03 ; \rho=-0.17)$ in blood of pregnant sows.

\section{Discussion}

\subsection{Immune Cell Numbers and Cortisol Concentration during Pregnancy}

The present study provides a detailed picture of blood immune cell numbers during the entire pregnancy in sows. A decrease in the number of most lymphocyte subsets characterizes the immunological profile of sows, especially towards the end of pregnancy. This finding is generally in line with previous results in humans, rodents, and swine $[1,2,4,15]$. The results are also in accordance with our own previous study [16], in which blood lymphocyte subsets were analyzed in detail during the second half of gestation. This present report shows that not all lymphocyte subsets follow the same pattern, especially during the first half of pregnancy. Despite a general trend towards decreased immune cells, $\mathrm{CD}^{-} \gamma \delta-\mathrm{T}$ cells are increased at the beginning of pregnancy. This increase may be of particular relevance as $\gamma \delta-T$ cells represent a major T cell subpopulation of peripheral blood lymphocytes in swine, which perform various important effector functions, such as cytotoxic activity or cytokine production [46]. The view that immune changes start already at early pregnancy in sows is further supported by an early decline in antigen-experienced CD $8 \alpha^{+} \mathrm{TH}$ cells, which play an important role in immunological memory functioning [46,47].

Two earlier studies published in 1984 and 1992 also examined total blood T-lymphocytes during the entire pregnancy in sows. The findings, however, obtained by using non-flow cytometric techniques, differ from our results and those found in other species. Georgieva [12] reported no changes for blood TH cells during pregnancy, while Schollenberger et al. [13] showed an increase of blood TH and B cells only during middle and late pregnancy.

As already demonstrated for other species [8-10,48], the number of blood neutrophil granulocytes increased during pregnancy in the sows examined for the present study. Since circulating granulocytes often show an activated phenotype in normal pregnancy [1,9,49], an increased number of granulocytes may partially compensate for a weakened maternal-specific immunity.

Pigs differ from other species, like rodents, insofar as the number of monocytes decreases during pregnancy. It might be possible that in pigs, increased monocytes would pose a risk for pregnancy as very high numbers of circulating monocytes correlate with preeclampsia and might cause damage to the fetus as it was shown in humans $[9,50]$. At present, however, the reason for this discrepancy as well as probable impacts for pregnancy in pigs is unclear and is surely a worthwhile focus for future research.

The pregnancy-associated change in peripheral lymphocyte numbers is likely to result from a redistribution of immune cells into other tissues, including the reproductive tract $[51,52]$. Recent studies in humans have shown that some $\mathrm{T}$ cell subpopulations are selectively recruited from peripheral blood to the decidua during pregnancy [52,53]. Bischof et al. [54] found pregnancy-induced changes in the uterine lymph nodes of pregnant sows with an increase in the proportion of B cells and in the $\mathrm{CD} 4 / \mathrm{CD} 8^{\mathrm{H}}$ ratio. This redistribution might explain the decrease in numbers of blood $\mathrm{B}$ cells and of some T cell subsets in pregnant sows. The action of steroid hormones might be part of the underlying mechanism for this redistribution. Glucocorticoids are naturally increased at the end of pregnancy [55-58] for fetal brain and lung development, but are also major mediators of leukocyte distribution [29]. Moreover, maternal and placental hormones, such as estrogen or progesterone, could be responsible for the reduction of circulating $\mathrm{TH}$ and cytotoxic $\mathrm{T}$ cells as well as for the apoptosis of effector T cells [9,58-61]. 


\subsection{Changes in Immune Cell Numbers and Cortisol Concentration Associated with Social Status}

Our data show that a sow's social status is related to blood immune cell numbers during pregnancy. Most rank-dependent particularities were seen in middle-ranking sows. In particular, the higher numbers of $B$ cells differ from low-ranking sows and the higher number of monocytes deviates from low- and high-ranking sows. B cells actively contribute to well-being during pregnancy, for example, by the production of protective antibodies. They may, however, also contribute to pregnancy-associated pathologies because of the production of autoantibodies [62]. A higher number of $B$ cells and monocytes in middle-ranking sows may therefore point to imbalances between immune activation and tolerance. Moreover, an effective immune response requires an appropriate migration pattern of $B$ cells to lymph nodes or other relevant lymphatic organs [63,64]. Higher numbers of B cells in middle-ranking sows may indicate that this process is impaired. An elevated number of $B$ cells may also stem from an extended life span of B cells. In middle-ranking sows, this would mean a deviation from the "normal" status in which the majority of the mature B lymphocytes in the periphery have a short life expectancy [65].

Why is it justified to assume that middle-ranking sows deviate from normal status and why do these sows differ from low- and high-ranking sows? Middle-ranking sows have to challenge dominant sows to improve their social status while simultaneously defending their own status against subdominants. According to Mendl et al. [27], high social status (and continued success) as well as the acceptance of low status (and no success) have lower physiological costs than a middle rank status. Under such conditions, increased cortisol levels were found in middle-ranking sows $[26,27]$. Although in the present study, blood cortisol concentrations were just slightly increased in middle-ranking sows, the immunological parameters point to stressful social conflicts during dominance establishment [66,67]. Monocytosis [17], lower numbers of some T cell populations compared to HR sows at some points, and a negative correlation between cortisol levels and numbers of blood T and TH cells support the assumption of a contribution of the hypothalamus-pituitary-adrenal (HPA) axis hormones to the immune cells of pregnant sows. The effect on B cells in MR sows could also be explained by glucocorticoid action, because stressful conditions or treatment with dexamethasone have been shown to increase the number of $B$ cells $[63,68,69]$. However, it should be noted that the stress effects on B cells are complex, as decreased B cell numbers have also been observed in response to stressors $[67,70]$. It is apparent that more research is needed to clarify the interactions of social stress and rank position and their effects on immune cell distribution to unravel these associations.

Future studies should investigate the hormonal influences in more detail. It is known that plasma levels of cortisol can be influenced by the time of sampling, as the activity of the HPA axis is highly variable and porcine plasma cortisol concentrations were also found to show their highest peak in the morning [36,71]. Cortisol levels thus might have been elevated before sampling in the middle-ranking sows of the present study, but had already declined to baseline at the time of measurement. More insight will also come from assessment of corticosteroid-binding globulin as well as catecholamines. Moreover, although stress is a prime candidate for explaining the immune status in middle-ranking sows, it might not be the only factor. Rank-dependent differences in physical activity or a shift in diurnal rhythms may also play a role [36].

Finally, it should be recognized that social rank, although associated with altered absolute blood immune cell numbers, did not disrupt the normal pattern of pregnancy-associated immune changes in sows. This would suggest that a finely tuned balance between innate and adaptive immune cells is of essential importance for a successful pregnancy and is relatively resistant against stress-induced alterations.

\section{Conclusions}

The analysis of blood immune cell subsets in sows shows that pregnancy-associated immunomodulations exist in each trimester of pregnancy and future studies on the effects of social stress on the immune system in pregnant pigs should ideally cover the entire gestation period. The 
rank-specific analysis revealed that middle-ranking sows showed distinct changes in the immune system, such as monocytosis and a decrease of some $\mathrm{T}$ cell subsets. These immunological changes are best interpreted as a stress response, but some open questions remain, such as the role of cortisol and the effects on B cells. The results of the present study are of relevance for livestock production as they indicate that a low social status may not (always) be the most stressful condition. Instead, it appears that middle-ranking positions in group-housing environments could be associated with more adverse effects on welfare and health.

Author Contributions: C.S., B.P., S.S., and V.S. conceived and designed research; C.S. conducted and performed experiments and analyzed data; B.P., S.S., U.W. and V.S. contributed materials and analysis tools; C.S. wrote and edited the paper; B.P., S.S., U.W. and V.S. reviewed the paper.

Funding: This research was supported by scholarships to C.S. from the Faculty of Agricultural Sciences, University of Hohenheim, Stuttgart, Germany, and from the H. Wilhelm Schaumann Stiftung, Hamburg, Germany.

Acknowledgments: The authors thank Eberhard Reichenecker, Christoph Albert, Nadine Münzenmeier, and Severin Datzer of the experimental unit "Unterer Lindenhof" for animal care, and the veterinarians of the Schweinegesundheitsdienst Baden-Württemberg Ernst Lohner, Ralf Igelbrink, and Agnes Richter for their support and advice on blood collection. We also thank Larissa Engert, Felix Haukap, Charlotte Heyer, Sybille Knöllinger, and Petra Veit for technical assistance, and Sarah Geiger and Stefanie Holbein for their support during the experimental procedure and on video analysis. We are grateful to Filippo Capezzone for statistical advice. Furthermore, we thank Oliver Sanders and the Institute of Animal Welfare and Husbandry (Friedrich-Loeffler-Institut, Celle, Germany) for providing software for video recording and Christine Frasch for proof-reading.

Conflicts of Interest: The authors declare no conflict of interest. The funders had no role in the design of the study, in the collection, analysis, or interpretation of data, in the writing of the manuscript, or in the decision to publish the results.

\section{References}

1. Luppi, P. How immune mechanisms are affected by pregnancy. Vaccine 2003, 21, 3352-3357. [CrossRef]

2. Ramsay, M. Normal and the cellular puerperium changes during pregnancy. In The Obstetric Hematology Manual; Pavord, S., Hunt, B., Eds.; Cambridge University Press: New York, NY, USA, 2018; pp. 3-59, ISBN 1108547273.

3. Nakamura, H.; Seto, T.; Nagase, H.; Yoshida, M.; Dan, S.; Ogino, K. Inhibitory effect of pregnancy on stress-induced immunosuppression through corticotropin releasing hormone (CRH) and dopaminergic systems. J. Neuroimmunol. 1997, 75, 1-8. [CrossRef]

4. Stefanski, V.; Raabe, C.; Schulte, M. Pregnancy and social stress in female rats: Influences on blood leukocytes and corticosterone concentrations. J. Neuroimmunol. 2005, 162, 81-88. [CrossRef] [PubMed]

5. Watanabe, M.; Iwatani, Y.; Kaneda, T.; Hidaka, Y.; Mitsuda, N.; Morimoto, Y.; Amino, N. Changes in T, B, and NK lymphocyte subsets during and after normal pregnancy. Am. J. Reprod. Immunol. 1997, 37, 368-377. [CrossRef]

6. Pazos, M.; Sperling, R.S.; Moran, T.M.; Kraus, T.A. The influence of pregnancy on systemic immunity. Immunol. Res. 2012, 54, 254-261. [CrossRef] [PubMed]

7. Kwak-Kim, J.; Bao, S.; Lee, S.K.; Kim, J.W.; Gilman-Sachs, A. Immunological modes of pregnancy loss: Inflammation, immune effectors, and stress. Am. J. Reprod. Immunol. 2014, 72, 129-140. [CrossRef] [PubMed]

8. Kühnert, M.; Strohmeier, R.; Stegmüller, M.; Halberstadt, E. Changes in lymphocyte subsets during normal pregnancy. Eur. J. Obstet. Gynecol. Reprod. Biol. 1998, 76, 147-151. [CrossRef]

9. Sacks, G.; Sargent, I.; Redman, C. An innate view of human pregnancy. Immunol. Today 1999, $20,114-118$. [CrossRef]

10. Luppi, P.; Haluszczak, C.; Trucco, M.; Deloia, J.A. Normal pregnancy is associated with peripheral leukocyte activation. Am. J. Reprod. Immunol. 2002, 47, 72-81. [CrossRef] [PubMed]

11. Elbers, A.R.W.; Geudeke, M.J.; van Rossem, H.; Kroon, M.C.; Counotte, C.H.M. Haematology and biochemistry reference values for sows kept under modern management conditions. Vet. Q. 1994, 16, 127-130. [CrossRef] [PubMed]

12. Georgieva, R. Dynamics of T-suppressor and T-helper lymphocytes and haemolytic plaque-forming cells during normal pregnancy in the sow. J. Reprod. Immunol. 1984, 6, 151-156. [CrossRef] 
13. Schollenberger, A.; Degorski, A.; Bielecki, W.; Stempniak, M. Lymphocyte subpopulations in peripheral blood of pregnant sows. Arch. Vet. Pol. 1992, 32, 35-46. [PubMed]

14. Žvorc, Z.; Mrljak, V.; Sušic, V.; Gotal, J.P. Haematological and biochemical parameters during pregnancy and lactation in sows. Vet. Arh. 2006, 76, 245-253.

15. Couret, D.; Otten, W.; Puppe, B.; Prunier, A.; Merlot, E. Behavioural, endocrine and immune responses to repeated social stress in pregnant gilts. Animal 2009, 3, 118-127. [CrossRef]

16. Grün, V.; Schmucker, S.; Schalk, C.; Flauger, B.; Weiler, U.; Stefanski, V. Influence of different housing systems on distribution, function and mitogen-response of leukocytes in pregnant sows. Animals 2013, 3, 1123-1141. [CrossRef] [PubMed]

17. Engler, H.; Bailey, M.T.; Engler, A.; Sheridan, J.F. Effects of repeated social stress on leukocyte distribution in bone marrow, peripheral blood and spleen. J. Neuroimmunol. 2004, 148, 106-115. [CrossRef] [PubMed]

18. Stefanski, V. Social stress in laboratory rats: Hormonal responses and immune cell distribution. Psychoneuroendocrinology 2000, 25, 389-406. [CrossRef]

19. Grün, V.; Schmucker, S.; Schalk, C.; Flauger, B.; Stefanski, V. Characterization of the adaptive immune response following immunization in pregnant sows (Sus scrofa) kept in two different housing systems. J. Anim. Sci. 2014, 92, 3388-3397. [CrossRef] [PubMed]

20. Schalk, C.; Pfaffinger, B.; Schmucker, S.; Weiler, U.; Stefanski, V. Effects of repeated social mixing on behavior and blood immune cells of group-housed pregnant sows (Sus scrofa domestica). Livest. Sci. 2018, 217, 148-156. [CrossRef]

21. Chebel, R.C.; Silva, P.R.B.; Endres, M.I.; Ballou, M.A.; Luchterhand, K.L. Social stressors and their effects on immunity and health of periparturient dairy cows1. J. Dairy Sci. 2016, 99, 3217-3228. [CrossRef]

22. O'Connell, N.E.; Beattie, V.E.; Moss, B.W. Influence of social status on the welfare of sows in static and dynamic groups. Anim. Welf. 2003, 12, 239-249.

23. Li, Y.Z.; Wang, L.H.; Johnston, L.J. Effects of social rank on welfare and performance of gestating sows housed in two group sizes. J. Swine Health Prod. 2017, 6, 290-298.

24. Hoy, S.; Bauer, J.; Borberg, C.; Chonsch, L.; Weirich, C. Investigations on dynamics of social rank of sows during several parities. Appl. Anim. Behav. Sci. 2009, 121, 103-107. [CrossRef]

25. Tsuma, V.T.; Einarsson, S.; Madej, A.; Kindahl, H.; Lundeheim, N.; Rojkittikhun, T. Endocrine changes during group housing of primiparous sows in early pregnancy. Acta Vet. Scand. 1996, 37, 481. [PubMed]

26. Zanella, A.J.; Brunner, P.; Unshelm, J.; Mendl, M.T.; Broom, D.M. The relationship between housing and social rank on cortisol, $\beta$-endorphin and dynorphin (1-13) secretion in sows. Appl. Anim. Behav. Sci. 1998, 59, 1-10. [CrossRef]

27. Mendl, M.; Zanella, A.J.; Broom, D.M. Physiological and reproductive correlates of behavioural strategies in female domestic pigs. Anim. Behav. 1992, 44, 1107-1121. [CrossRef]

28. Verdon, M.; Morrison, R.S.; Rice, M.; Hemsworth, P.H. Individual variation in sow aggressive behavior and its relationship with sow welfare. J. Anim. Sci. 2016, 94, 1203-1214. [CrossRef] [PubMed]

29. Dhabhar, F.S.; Miller, A.H.; McEwen, B.S.; Spencer, R.L. Stress-induced changes in blood leukocyte distribution. Role of adrenal steroid hormones. J. Immunol. 1996, 157, 1638-1644.

30. Dhabhar, F.S. Stress-induced augmentation of immune function-The role of stress hormones, leukocyte trafficking, and cytokines. Brain Behav. Immun. 2002, 16, 785-798. [CrossRef]

31. Zhao, Y.; Flowers, W.L.; Saraiva, A.; Yeum, K.-J.; Kim, S.W. Effect of social ranks and gestation housing systems on oxidative stress status, reproductive performance, and immune status of sows1. J. Anim. Sci. 2013, 91, 5848-5858. [CrossRef] [PubMed]

32. Pacheco, E.; Salak-Johnson, J.L. Social status affects welfare metrics of group-housed gestating sows. J. Vet. Res. Anim. Husb. 2016, 1, 103.

33. Sutherland, M.A.; Niekamp, S.R.; Johnson, R.W.; van Alstine, W.G.; Salak-Johnson, J.L. Heat and social rank impact behavior and physiology of PRRS-virus-infected pigs. Physiol. Behav. 2007, 90, 73-81. [CrossRef] [PubMed]

34. Hjarvard, B.M.; Larsen, O.N.; Juul-Madsen, H.R.; Jørgensen, E.; Jensen, K.H. Social rank influences the distribution of blood leukocyte subsets in female growing pigs. Scandinavian J. Lab. Anim. Sci. 2009, 36, 309-320. 
35. Engert, L.C.; Weiler, U.; Stefanski, V.; Schmucker, S.S. Glucocorticoid receptor number and affinity differ between peripheral blood mononuclear cells and granulocytes in domestic pigs. Domest. Anim. Endocrinol. 2017, 61, 11-16. [CrossRef] [PubMed]

36. Engert, L.C.; Weiler, U.; Pfaffinger, B.; Stefanski, V.; Schmucker, S.S. Diurnal rhythms in peripheral blood immune cell numbers of domestic pigs. Dev. Comp. Immunol. 2018, 79, 11-20. [CrossRef] [PubMed]

37. Horback, K.M.; Parsons, T.D. Temporal stability of personality traits in group-housed gestating sows. Animal 2016, 10, 1-9. [CrossRef] [PubMed]

38. Jensen, P. An ethogram of social interaction patterns in group-housed dry sows. Appl. Anim. Ethol. 1980, 6, 341-350. [CrossRef]

39. De Silva, S.; Schmid, V.; Wittemyer, G. Fission-fusion processes weaken dominance networks of female Asian elephants in a productive habitat. Behav. Ecol. 2017, 28, 243-252. [CrossRef]

40. Hemelrijk, C.K.; Wantia, J.; Gygax, L. The construction of dominance order: Comparing performance of five methods using an individual-based model. Behaviour 2005, 142, 1037-1058. [CrossRef]

41. Zumpe, D.; Michael, R.P. Dominance index: A simple measure of relative dominance status in primates. Am. J. Primatol. 1986, 10, 291-300. [CrossRef]

42. R Development Core Team. R: A language and Environment for Statistical Computing (3.1.0). 2015. Available online: http:/ / www.r-project.org (accessed on 31 January 2015).

43. Bates, D.; Maechler, M.; Bolker, B.; Walker, S. lme4: Linear Mixed-Effects Models Using Eigen and S4. 2016. Available online: http:/ /CRAN.R-project.org/package=lme4 (accessed on 31 January 2016).

44. Langer, F.; Havenstein, N.; Fietz, J. Flexibility is the key: Metabolic and thermoregulatory behaviour in a small endotherm. J. Comp. Physiol. B 2018, 188, 553-563. [CrossRef] [PubMed]

45. Hothorn, T.; Bretz, F.; Westfall, P. Simultaneous inference in general parametric models. Biom. J. 2008, 50, 346-363. [CrossRef] [PubMed]

46. Charerntantanakul, W.; Roth, J.A. Biology of porcine T lymphocytes. Anim. Health Res. Rev. 2006, 7, 81-96. [CrossRef] [PubMed]

47. Gerner, W.; Käser, T.; Saalmüller, A. Porcine T lymphocytes and NK cells-An update. Dev. Comp. Immunol. 2009, 33, 310-320. [CrossRef] [PubMed]

48. Papworth, T.A.; Clubb, S.K. Clinical pathology in the female rat during the pre-and postnatal period. Comp. Haematol. Int. 1995, 5, 13-24. [CrossRef]

49. Shibuya, T.; Izuchi, K.; Kuroiwa, A.; Okabe, N.; Shirakawa, K. Study on nonspecific immunity in pregnant women: Increased chemiluminescence response of peripheral blood phagocytes. Am. J. Reprod. Immunol. 1987, 15, 19. [CrossRef]

50. Sargent, I.L.; Borzychowski, A.M.; Redman, C.W.G. Immunoregulation in normal pregnancy and pre-eclampsia: An overview. Reprod. Biomed. Online 2006, 13, 680-686. [CrossRef]

51. McLean, J.M.; Mosley, J.G.; Gibbs, A.C. Changes in the thymus, spleen and lymph nodes during pregnancy and lactation in the rat. J. Anat. 1974, 118, 223. [PubMed]

52. Lee, S.K.; Kim, C.J.; Kim, D.-J.; Kang, J.-H. Immune cells in the female reproductive tract. Immune Netw. 2015, 15, 16-26. [CrossRef]

53. Tilburgs, T.; Roelen, D.L.; van der Mast, B.J.; de Groot-Swings, G.M.; Kleijburg, C.; Scherjon, S.A.; Claas, F.H. Evidence for a Selective Migration of Fetus-Specific CD4+CD25bright Regulatory T Cells from the Peripheral Blood to the Decidua in Human Pregnancy. J. Immunol. 2008, 180, 5737-5745. [CrossRef] [PubMed]

54. Bischof, R.J.; Lee, R.; Lee, C.-S.; Meeusen, E. Dynamic changes in the lymphocyte subpopulations of pig uterine lymph nodes. Vet. Immunol. Immunopathol. 1996, 51, 315-324. [CrossRef]

55. Zhang, M.-Y.; Li, X.; Zhang, X.-H.; Liu, H.-G.; Li, J.-H.; Bao, J. Effects of confinement duration and parity on stereotypic behavioral and physiological responses of pregnant sows. Physiol. Behav. 2017, 179, 369-376. [CrossRef] [PubMed]

56. Takahashi, L.K.; Turner, J.G.; Kalin, N.H. Prolonged stress-induced elevation in plasma corticosterone during pregnancy in the rat: Implications for prenatal stress studies. Psychoneuroendocrinology 1998, 23, 571-581. [CrossRef]

57. Mastorakos, G.; Ilias, I. Maternal and fetal hypothalamic-pituitary-adrenal axes during pregnancy and postpartum. Ann. N. Y. Acad. Sci. 2003, 997, 136-149. [CrossRef] [PubMed]

58. Robinson, D.P.; Klein, S.L. Pregnancy and pregnancy-associated hormones alter immune responses and disease pathogenesis. Horm. Behav. 2012, 62, 263-271. [CrossRef] [PubMed] 
59. Grossman, C.J. Interactions between the gonadal steroids and the immune system. Science 1985, 227, $257-262$. [CrossRef] [PubMed]

60. Piccinni, M.-P.; Giudizi, M.-G.; Biagiotti, R.; Beloni, L.; Giannarini, L.; Sampognaro, S.; Parronchi, P.; Manetti, R.; Annunziato, F.; Livi, C. Progesterone favors the development of human T helper cells producing Th2-type cytokines and promotes both IL-4 production and membrane CD30 expression in established Th1 cell clones. J. Immunol. 1995, 155, 128-133. [PubMed]

61. Schumacher, A.; Costa, S.-D.; Zenclussen, A.C. Endocrine factors modulating immune responses in pregnancy. Front. Immunol. 2014, 5, 196. [CrossRef] [PubMed]

62. Muzzio, D.; Zenclussen, A.C.; Jensen, F. The role of B cells in pregnancy: The good and the bad. Am. J. Reprod. Immunol. 2013, 69, 408-412. [CrossRef]

63. Stefanski, V. Social stress in loser rats: Opposite immunological effects in submissive and subdominant males. Physiol. Behav. 1998, 63, 605-613. [CrossRef]

64. Ottaway, C.A.; Husband, A.J. Central nervous system influences on lymphocyte migration. Brain Behav. Immun. 1992, 6, 97-116. [CrossRef]

65. Freitas, A.A.; Rocha, B.; Coutinho, A.A. Life span of B lymphocytes: The experimental basis for conflicting results. J. Immunol. 1986, 136, 470-476. [PubMed]

66. Sachser, N.; Dürschlag, M.; Hirzel, D. Social relationships and the management of stress. Psychoneuroendocrinology 1998, 23, 891-904. [CrossRef]

67. Stefanski, V.; Engler, H. Social stress, dominance and blood cellular immunity. J. Neuroimmunol. 1999, 94, 144-152. [CrossRef]

68. Anderson, B.H.; Watson, D.L.; Colditz, I.G. The effect of dexamethasone on some immunological parameters in cattle. Vet. Res. Commun. 1999, 23, 399-413. [CrossRef] [PubMed]

69. Landmann, R.M.; Müller, F.B.; Perini, C.H.; Wesp, M.; Erne, P.; Bühler, F.R. Changes of immunoregulatory cells induced by psychological and physical stress: Relationship to plasma catecholamines. Clin. Exp. Immunol. 1984, 58, 127. [PubMed]

70. Dhabhar, F.S.; Miller, A.H.; McEwen, B.S.; Spencer, R.L. Effects of stress on immune cell distribution. Dynamics and hormonal mechanisms. J. Immunol. 1995, 154, 5511-5527. [PubMed]

71. Mormède, P.; Andanson, S.; Aupérin, B.; Beerda, B.; Guémené, D.; Malmkvist, J.; Manteca, X.; Manteuffel, G.; Prunet, P.; van Reenen, C.G.; et al. Exploration of the hypothalamic-pituitary-adrenal function as a tool to evaluate animal welfare. Physiol. Behav. 2007, 92, 317-339. [CrossRef] [PubMed] 